\title{
Advanced Energy Storage Life and Health Prognostics (INL)
}

\author{
Jon P. Christophersen
}

November 2011

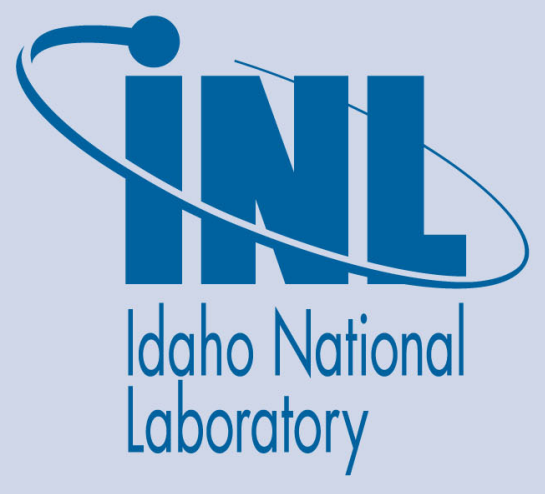

The INL is a U.S. Department of Energy National Laboratory operated by Battelle Energy Alliance 
INL/EXT-11-23791

\title{
Advanced Energy Storage Life and Health Prognostics (INL)
}

\author{
Jon P. Christophersen
}

November 2011

\section{Idaho National Laboratory \\ Idaho Falls, Idaho 83415}

http://www.inl.gov

\section{Prepared for the}

U.S. Department of Energy

Assistant Secretary for Energy Efficiency and Renewable Energy Under DOE Idaho Operations Office

Contract DE-AC07-05ID14517 


\section{III.D.2 Advanced Energy Storage Life and Health Prognostics (INL)}

\author{
Jon P. Christophersen \\ Idaho National Laboratory (INL) \\ P.O. Box 1625 \\ Idaho Falls, ID 83415 \\ Phone: (208) 526-4280; Fax: (208) 526-0690 \\ E-mail: jon.christophersen@inl.gov \\ Collaborators: \\ Ira Bloom, ANL (BLE) \\ Clair Ashton, INL (BLE) \\ David Robertson, ANL (BLE) \\ John Morrison, Montana Tech (ESMS) \\ William Morrison, Qualtech Systems, Inc. \\ (ESMS) \\ Chinh Ho, INL (ESMS) \\ Start Date: October, 2008 \\ Projected End Date: Ongoing
}

\section{Objectives}

The objective of this work is to develop methodologies that will accurately estimate state-ofhealth (SOH) and remaining useful life (RUL) of electrochemical energy storage devices using both offline and online (i.e., in-situ) techniques through:

- Developing a statistically robust battery life estimator tool based on both testing and simulation,

- Developing rapid impedance spectrum measurement techniques that enable onboard power assessment, and

- $\quad$ Developing an energy storage monitoring system that incorporates both passive and active measurements for onboard systems.

\section{Technical Barriers}

Presently, there are no adopted standards for assessing battery SOH and RUL and the U.S. automotive industry is confronted with the possibility of over-sizing batteries (thus increasing weight and cost) to minimize warranty claim issues and to ensure the required 15 -year calendar life is met. This work addresses two primary technical barriers that impact battery $\mathrm{SOH}$ estimation: offline aging using statistically-based methods to accurately establish battery life estimation (BLE) with a given upper and lower confidence limit and the development of an online, rapid assessesment of battery health with an onboard Energy Storage Monitoring System (ESMS) that incorporates both passive and active measurements.

\section{Technical Targets}

- Assess the memory of battery technologies with a non-isothermal study to establish effects of path dependence.

- Update Battery Life Estimator Manual to include a non-linear model description and path dependence effects.

- Develop hardware and software for rapid in-situ impedance measurements that can be applied to cells, modules, and packs.

- Validate in-situ impedance measurement technique as a viable prognostic tool.

- Design an embedded impedance measurement system for field testing (long term goal).

Design and build the overall energy storage monitoring system with passive observations, active measurements, and expert learning software tools (long term goal).

\section{Accomplishments}

- Initated path dependence study with high power Sanyo SA cells.

- $\quad$ Completed the initial round of validation tests for the rapid in-situ impedance measurement technique using Sanyo SA cells.

- Developed a novel calibration technique for the Impedance Measurement Box (IMB) that includes both magnitude and phase.

- Submitted two new patent applications for the IMB technology.

\section{Introduction}

Robust, life estimation and onboard state-of-health assessment techniques remain a critical need for the successful and widespread implementation of battery technologies for various applications (automotive, military, space, telecommunications, etc.). Due to the complexity of the problem, however, no industry standards have yet been adopted for $\mathrm{SOH}$ and RUL assessment. Idaho, Argonne, Sandia, and Lawrence Berkeley National Laboratories have been collaborating 
on an offline battery life estimation tool for determining overall battery life expectancy under typical stress conditions (e.g., 15 year calendar life and 150,000 miles) with a high statistical confidence and within a short period of testing time. It is primarily intended to help manufacturers determine a technology's readiness for mass production and could also serve as a useful adjunct in warranty determinations.

The Idaho National Laboratory is also collaborating with Montana Tech of the University of Montana and Qualtech Systems, Inc. on developing an online (in-situ) assessment of battery health through passive observations (e.g., voltage and current as a function of temperature) and active diagnostic tests. The active diagnostic tests primarily include rapid impedance measurements over a wide frequency range. Several novel impedance spectrum measurement techniques have been developed that can yield high resolution results within seconds. Information determined from onboard impedance measurements, when combined with other passive measurements, models, and expert learning software, enable the development of an overall Energy Storage Monitoring System that will be relevant to all industries that utilize expensive or mission-critical battery applications.

\section{Approach}

Battery Life Estimator. The purpose of the Sanyo SA cell testing for BLE applications is to assess their memory effects (if any) during non-isothermal aging conditions. The test matrix is shown in Table I and consists of 24 cells with three cells per test condition. The cells are being subjected to calendar-life tests at $60 \%$ SOC $(3.89 \mathrm{~V})$ with reference performance tests every 32 days. Idaho and Argonne National Laboratories have control groups at both 45 and $55^{\circ} \mathrm{C}$ to establish the baseline performance at each temperature as well as to verify consistency between labs. The first non-isothermal group consists of calendar-life aging at $55^{\circ} \mathrm{C}$ until the power fade reaches at least $15 \%$ and then switching to $45^{\circ} \mathrm{C}$ for the remaining calendar aging (ANL performs the same test, but with the temperatures reversed). The other non-isolthermal group consists of switching between 55 and $45^{\circ} \mathrm{C}$ during calendar life aging after each reference performance test (RPT). The battery size factor for these cells is 1400 . The data collected from this study will be incorporated into Revision 1 of the BLE Manual in addition to the nonlinear model software tool.
Table I: Sanyo SA cell test matrix for memory study

\begin{tabular}{|c|c|c|c|c|c|}
\hline Lab & $\begin{array}{c}\text { Group } \\
\#\end{array}$ & Type & Label & Cells & $\begin{array}{c}\text { Temp. } \\
\left({ }^{\circ} \mathrm{C}\right)\end{array}$ \\
\hline \multirow{4}{*}{ INL } & 1 & ISO-LO & Control & 3 & 45 \\
\hline & 2 & ISO-HI & Control & 3 & 55 \\
\hline & 3 & $\begin{array}{l}\text { NON- } \\
\text { ISO }\end{array}$ & Switch & 3 & $55 \rightarrow 45$ \\
\hline & 4 & $\begin{array}{l}\text { NON- } \\
\text { ISO }\end{array}$ & Pulse & 3 & $55 / 45$ \\
\hline \multirow{4}{*}{ ANL } & 5 & ISO-LO & Control & 3 & 45 \\
\hline & 6 & ISO-HI & Control & 3 & 55 \\
\hline & 7 & $\begin{array}{l}\text { NON- } \\
\text { ISO }\end{array}$ & Switch & 3 & $45 \rightarrow 55$ \\
\hline & 8 & $\begin{array}{c}\text { NON- } \\
\text { ISO } \\
\end{array}$ & Pulse & 3 & $45 / 55$ \\
\hline
\end{tabular}

Energy Storage Monitoring System. The purpose of the Sanyo SA cell testing for ESMS applications was to assess the long-term impact and capability of rapid in-situ impedance measurements under both no-load and load conditions compared to a control group. The rapid impedance measurement technique was implemented using Harmonic Compensated Synchronous Detection (HCSD) ${ }^{1,2}$ with a low-level, charge neutral input current excitation signal. The test matrix is shown in Table II and consists of accelerated aging at 40 and $50^{\circ} \mathrm{C}$. All cells were cycled using the charge-sustaining cycle-life profile ${ }^{3}$ at $60 \%$ SOC (3.89 $\mathrm{V})$ and a battery size factor of 1400 . The no-load cells received an HCSD measurement at each RPT and the cells under load were also subjected to periodic impedance measurements during cycling. No HCSD measurements were performed for the control cells. Results from the no-load studies are discussed herein. Assessment of the measurements under load has been discussed elsewhere ${ }^{4}$ and will also be published at a later date.

\footnotetext{
${ }^{1}$ J. P. Christophersen, C. G. Motloch, J. L. Morrison, I. B. Donnellan, and W. H. Morrison, "Impedance Noise Identification for State-ofHealth Prognostics," Proceedings from the 43rd Power Sources Conference (2008).

${ }^{2}$ J. L. Morrison and W. H. Morrison, "Method of Detecting System Function by Measuring Frequency Response," U.S. Patent No. 7,395,163 B1, July 1, 2008.

${ }^{3}$ Battery Test Manual for Plug-In Hybrid Electric Vehicles, DOE/ID11070. 2003.

4 J. P. Christophersen, "Battery State-of-Health Assessment Using a Near Real-Time Impedance Measurement Technique Under No-Load and Load Conditions," Montana State University Dissertation (2011)
} 
Table II: Sanyo SA cell test matrix for HCSD study

\begin{tabular}{cccc}
\hline \hline Group \# & Label & Cells & $\begin{array}{c}\text { Temp. } \\
\left({ }^{\circ} \mathbf{C}\right)\end{array}$ \\
\hline \hline 1 & Control & 3 & 40 \\
2 & Control & 3 & 50 \\
\hline 3 & No-Load & 3 & 40 \\
4 & Load & 3 & 40 \\
\hline 5 & No-Load & 3 & 50 \\
6 & Load & 3 & 50 \\
\hline \hline
\end{tabular}

\section{Results}

Battery Life Estimator. Most of the Sanyo SA cells have completed two RPTs. The "Pulse" groups (i.e., " $55 / 45$ " and " $45 / 55$ ") began testing a month later and are one RPT behind. Figure I shows the average discharge capacity degradation for each cell group. All cells show similar initial capacities, but the rate of degradation increases with increasing temperature, as expected. The rate of degradation through two months of calendar aging appears to be slightly higher for the cells testing at INL, but the results also seem to be internally consistent within each laboratory. Figure II shows the average available power at $500 \mathrm{Wh}$ for each cell group. The cells tested at ANL show a slightly larger initial power capability (approximately $65 \mathrm{~kW}$ at RPT0 compared to $58 \mathrm{~kW}$ for the INL cells) but the rates of degradation at each temperature group appear to be generally similar.

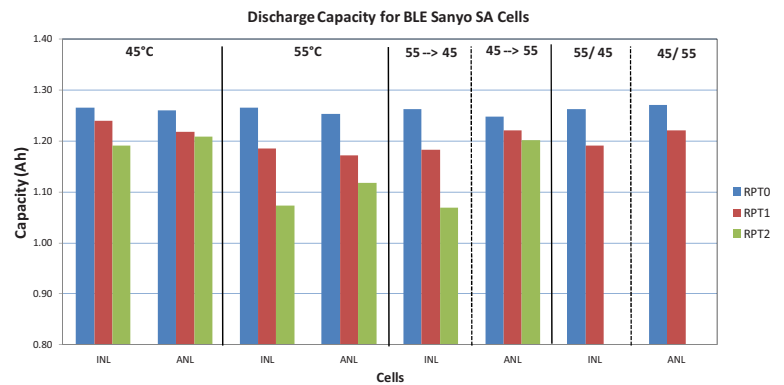

Figure I: Average discharge capacity for BLE Sanyo cells.

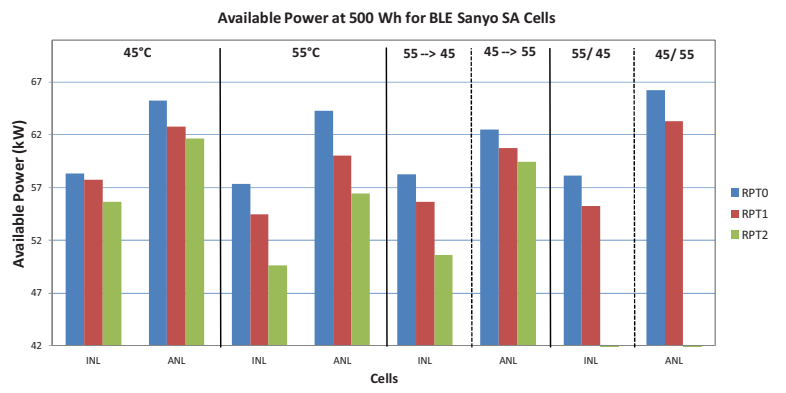

Figure II: Average power fade for BLE Sanyo cells.

Table III shows the average capacity and power fade for each cell group through RPT2 (the "Pulse" groups are shown in italics since they are the average fade results through RPT1). As shown, both the capacity and power fades are generally similar for each temperature group and laboratory. The power fade for the "Switch" groups have not yet reach $15 \%$ so the cells are continuing to be calendar-life aged at the original test temperature. However, given the rate of degradation, it is anticipated that the cells aged at $55^{\circ} \mathrm{C}$ will need to switch to the lower temperature after RPT3. Once more data are obtained, results from this study will be used to examine path dependence and memory effects of aging at different temperatures and incorporated into Revision 1 of the BLE Manual.

Table III: Sanyo SA cell test matrix for memory study

\begin{tabular}{ccccc}
\hline \hline Lab & Group \# & $\begin{array}{c}\text { Temp. } \\
\left({ }^{\circ} \mathbf{C}\right)\end{array}$ & $\begin{array}{c}\text { Capacity } \\
\text { Fade (\%) }\end{array}$ & $\begin{array}{c}\text { Power } \\
\text { Fade (\%) }\end{array}$ \\
\hline \hline \multirow{4}{*}{ INL } & 1 & 45 & $5.91 \%$ & $4.58 \%$ \\
& 2 & 55 & $15.24 \%$ & $13.48 \%$ \\
& 3 & $55 \rightarrow 45$ & $15.35 \%$ & $13.12 \%$ \\
- & 4 & $55 / 45$ & $5.68 \%$ & $5.02 \%$ \\
\hline & 5 & 45 & $4.02 \%$ & $5.50 \%$ \\
ANL & 6 & 55 & $10.78 \%$ & $12.12 \%$ \\
& 7 & $45 \rightarrow 55$ & $3.76 \%$ & $4.85 \%$ \\
& 8 & $45 / 55$ & $3.88 \%$ & $4.40 \%$ \\
\hline \hline
\end{tabular}

Energy Storage Monitoring System. The Sanyo SA cells were subjected to five cycle sets (i.e., 150,000 cycles) with reference performance tests every 30,000 cycles. Thus, the cells that were not part of the control group received a total of seven HCSD measurements (Characterization, RPT0, and every 30,000 cycles thereafter). The cells subjected to impedance measurements under load also received an additional 10,000 HCSD measurements during cycle life aging. Both the no-load and load cell groups showed similar degradation rates compared to the control group, which indicates that HCSD measurements are benign and do not have an impact on cell degradation.

Figure III shows the average HCSD impedance spectra for the $50^{\circ} \mathrm{C}$ cell group aged under no-load conditions. Note that each spectrum shown in this figure was acquired within ten seconds over a frequency range of $0.1 \mathrm{~Hz}$ to $1638.4 \mathrm{~Hz}$. The impedance at RPT0 (solid diamond symbols) is smaller than at Characterization (solid circle symbols) due to cell formation. After RPT0, both the ohmic and charge transfer resistance in the mid-frequerncy region grew with increasing cycle sets and test temperature. 
Figure IV shows the average HCSD real impedance at the semicircle trough plotted against the HPPC discharge restance at $60 \%$ SOC for all four HCSD groups in Table II. The parameter values from the linear regression fits are summarized in Table IV. As shown, the data are highly correlated $\left(r^{2}>0.94\right)$ between these two independently determined parameters. Additionally, the slope of the linear fit is similar regardless of test temperature and number of insitu impedance measurements during cycling $(10,000$ additional measurements for the "Under Load" cells). These data indicate HCSD is a benign test that can accurately reflect growth in the HPPC pulse resistance as a function of cell age.

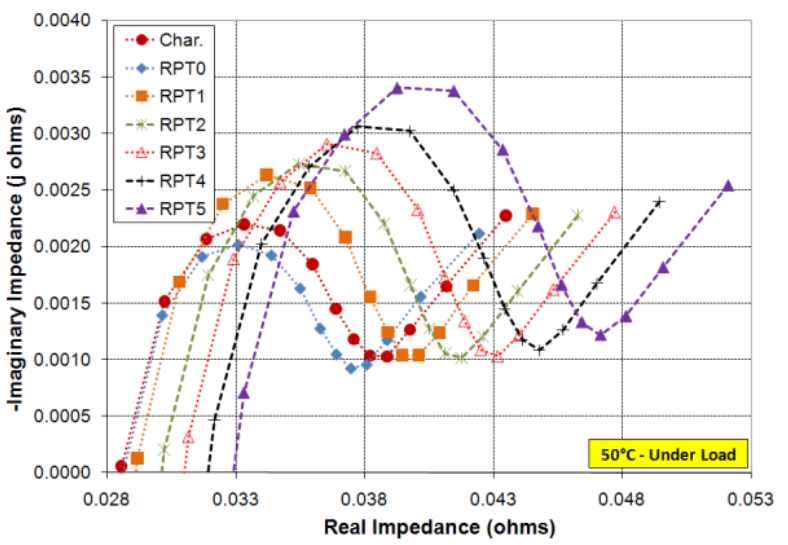

Figure III: Average HCSD measurement at $50^{\circ} \mathrm{C}$ for the no-load cell group.

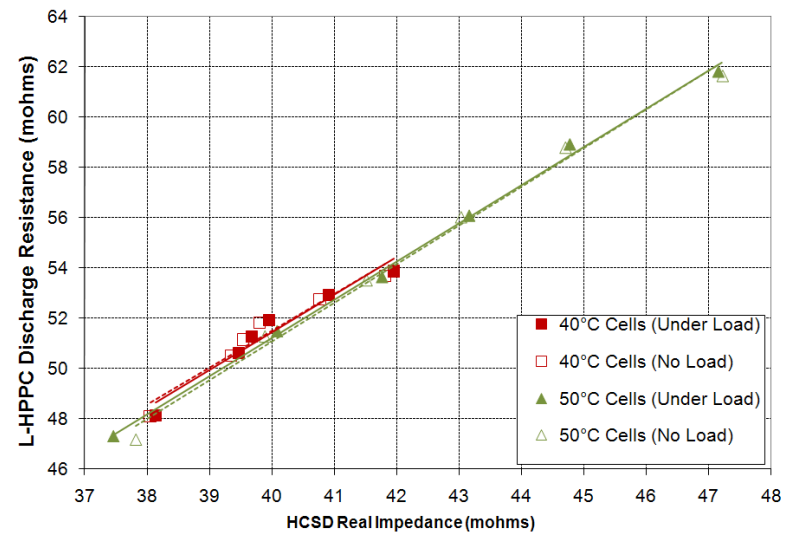

Figure IV: HCSD real impedance correlated to the HPPC discharge resistance.
Table IV: Sanyo SA cell test matrix for HCSD study

\begin{tabular}{|c|c|c|c|c|}
\hline $\begin{array}{c}\text { Temp. } \\
\left({ }^{\circ} \mathrm{C}\right)\end{array}$ & Label & Slope & $\begin{array}{c}\text { Intercept } \\
(\mathrm{m} \Omega)\end{array}$ & $r^{2}$ \\
\hline \multirow{2}{*}{$40^{\circ} \mathrm{C}$} & No- & 9 & -7.267 & 0.946 \\
\hline & & 1.503 & -8.674 & 0.954 \\
\hline \multirow{2}{*}{$\mathbf{5 0}$} & No-Loa & 1.543 & -10.635 & 0.992 \\
\hline & Load & 1.520 & -9.587 & 0.997 \\
\hline
\end{tabular}

\section{Conclusions and Future Directions}

The objective of the Battery Life Estimation manual is to develop a statistically robust offline life estimation tool that incorporates both standardized aging protocols and various off-normal degradation effects. Of particular interest is the memory effect when aging over different temperatures. A path dependence study was inintiated in FY-11 with Sanyo SA cells and expected to be completed in FY-12. The results will be incorporated into the next revision of the Battery Life Estimator manual.

The objective of the Energy Storage Monitoring System is to develop a rapid online state-of-health assessment technique. An initial validation study with Sanyo SA cells was completed in FY-11 which examined the effects of rapid impedance measurements under both no-load and load conditions. The results clearly indicated that Harmonic Compensated Synchronous Detection is a benign test that did not impact the rate of degradation. Additionally, results from the rapid impedance measurement were strongly correlated with the independently determined pulse tests from an HPPC. Validation studies are expected to continue in FY-12, including rapid impedance measurements over a broad range of state-of-charge conditions.

\section{FY 2011 Publications/Presentations}

1. J. P. Christophersen, I. Bloom, E. Thomas, V. Battaglia, "Developing Modeling Capability to Predict Life of Batteries," IEEE "Brew with the Crew" invited presentation, October 2010.

2. J. P. Christophersen, J. L. Morrison, W. H. Morrison, and C. G. Motloch, "In-Situ Real Time Energy Storage Device Impedance Identification," U.S. Patent Application, May 2011.

3. J. P. Christophersen, J. L. Morrison, W. H. Morrison, C. G. Motloch, and D. M. Rose, "Crosstalk Compensation in Analysis of Energy Storage Devices," U.S. Patent Application, May 2011. 
